\title{
LESSON 79
}

MARGINS: Pica, 20-70; Elite, 30-80.

Warm up

\section{Increase Speed}

25 wpm 5 minutes.

S34 - S! 1.09

\section{Improve Accuracy}

35 wpm 4 minutes.

A30 - SI 1.39

Test your Skill

4 minutes.

Use double-line spacing.

Change the margins to $25 \mathrm{~mm}$ and keep your right-hand margin as straight as possible.

T16 - SI 1.53
Type this sentence as many times as your teacher asks.

The ugly duckling was quite relieved to find, at last, he was a beautiful swan just like the one swimming so relaxed on the half frozen pool.

It is said that the best way to learn how you should do a job is to try it and see the snags. A good tip is to see how it is done by an expert who will give you a good idea of the best way to start it. If there is no one to show you, you must read what you can find on the job in books and see just what help the author can give you. In this case a good book can be a great aid but the use will best be made by those who can read instructions and see just what they mean. If you can see a film of the job as it is done by an expert it might be as good as having somebody with you to show you; until you need to ask a question, that is.

There are many different kinds of retail outlet and the smallest of them is the sole trader or the one man concern. The owner runs the business, and may or may not have paid employees to help him in the concern. Most sole traders are small since their size is limited to the amount of capital one person can raise either by saving up or borrowing.

A partnership is the next largest business in size normally as it is a concern which is owned by more than just one person. Several people working in a business concern can hope to raise a lot more cash than one. Again a partnership may use labour to assist in the running of the concern.

Both the sole trader and the partnership have unlimited liability.

The limited liability company is probably the most common sort of business unit. There are both public and private limited liability companies and they differ in several respects.

A private company may not offer its shares to the general public while those of a public company can be sold to the public. A private company as a general rule may have a maximum of 50 shareholders and a minimum of 2 but a public company by law has to have at least 7 shareholders. There is no real upper limit on the number of shareholders.

The use of limited liability encourages small investors to buy shares in large business units as they know exactly what they stand to lose - should the business fail - right from the start.

UNIT 20/CONSOLIDATION

\section{LESSON 79}

